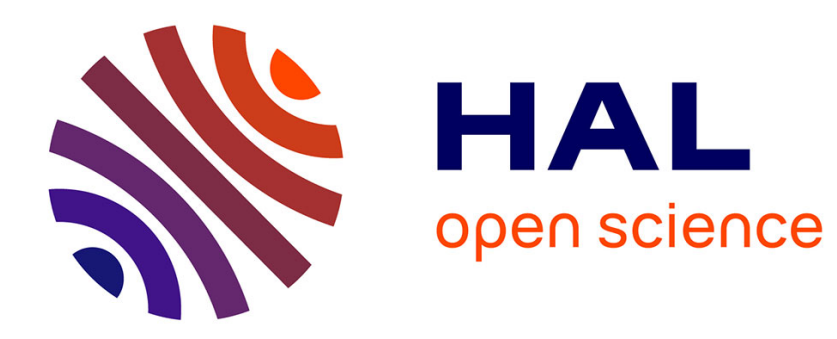

\title{
Densification behaviour of metal powders at high temperature
}

D. Bouvard, M. C. Cheynet

\section{To cite this version:}

D. Bouvard, M. C. Cheynet. Densification behaviour of metal powders at high temperature. Revue de Physique Appliquée, 1988, 23 (4), pp.701-701. 10.1051/rphysap:01988002304070100 . jpa-00245857

\section{HAL Id: jpa-00245857 https://hal.science/jpa-00245857}

Submitted on 1 Jan 1988

HAL is a multi-disciplinary open access archive for the deposit and dissemination of scientific research documents, whether they are published or not. The documents may come from teaching and research institutions in France or abroad, or from public or private research centers.
L'archive ouverte pluridisciplinaire HAL, est destinée au dépôt et à la diffusion de documents scientifiques de niveau recherche, publiés ou non, émanant des établissements d'enseignement et de recherche français ou étrangers, des laboratoires publics ou privés. 


\title{
DENSIFICATION BEHAVIOUR OF METAL POWDERS AT HIGH TEMPERATURE
}

\author{
D. BOUVARD and M.C. CHEYNET * \\ Institut de Mécanique de Grenoble, \\ BP 68, 38402 Saint Martin d'Hères, France \\ "Laboratoire de Thermodynamique et Physico-Chimie Métallurgiques, \\ BP 75, 38402 Saint Martin d'Hères, France
}

\section{INTRODUCTION}

Hot pressing is a technique used increasingly to densify hard to work metal and ceramic powders. However the mechanisms of densification have just started being realistically analysed and modelled (1). The main impediment to significant advancement seems to be the lack of suitable experimental results, which require indeed heavy testing programs.

In this paper we present the results of such a program realized on a powder superalloy and an analytical model for the densification of monosized spherical particles under isotropic pressure.

\section{EXPERIMENTAL WORK (2)}

A great number of interrupted hot isostatic pressing tescs was performed on two particle size discributions of argon atomized nickel base superalloy René 95 powder at different temperatures. The paritially densified specimens were analysed from two points of view :

- Bulk density measures permitted to estimate the densification rate as a function of relative density for each condition of temperature and paricle size distribution.

- Microscopic observations showed in particular that the morphological and microstructural changes of the particles depend on their initial structure. When most of the dendritic particles remain in their initial shape and structure, all the others are largely deformed and recrystallized during the densification. We observed also that, in the tesied conditions, interparticle diffusion is not significant up to $95 \%$ of density, at least.

These results permitted to explain the difference in densification rate between the two lots of powder and provided valuable informacion for a theoretical description of the compaction.

\section{MODELLING OF DENSIFICATION (3)}

We consider a random arrangement of monosized spherical particles submitted to an external isotropic pressure. The constituent material is incompressible and deforms by power law creep. We do nor take account of the diffusion-related mechanisms that have often litile effect on the densification, except for high densities.

We introduce "internal parameters" characterizing the particle deformation, as for example the interparticle contact area and the interparticle force. These parameters are supposed to be random variables, since they take different values within the material.

An equation describing the deformation of two contacting spheres is assumed and general relations between the internal parameters and the macroscopic parameters, which are the external pressure and the relative density, are displayed. Then, after an estimation of the statistical distribution of the random variables, an analytical expression of the densification rate is proposed.

The comparison of the densification rate determined for the Rene 95 powder with the prediction of the model is rather satisfactory, although the real particle size distribution does not agree with the hypothesis of the model.

\section{CONCLUSION}

These results are a first step towards a complete, realistic modelling of powder densification, that is expected to be directly usable for the selection of the main process parameters from the macro- and microscopic properties of the powder.

The present subjects of investigation concern the introduction of morphological and microstructural characteristics of the material in the model and the influence of deviatoric stresses on the densification rate.

\section{REFERENCES}

1 E. Arzt, M.F. Ashby, K.E. Easterling, Metal1. Trans., 14A, 211 (1983).

2 D. Bouvard, M.C. Cheynet, F. Saint-Antonin, Proc. 3rd Int. Conf. on Isostatic Pressing, Londres, 1986.

3 D. Bouvard, E. Quedraogo, Acta Met., to be published. 